\title{
Benzene Monitoring and S-Phenylmercapturic Acid Determination of Workers at Oil Sites in Congo-Brazzaville
}

\author{
Ebenguela Ataboho Ebatetou ${ }^{1,2 *}$, Josué Richard Ntsimba Nsemi², Donatien Moukassa² \\ ${ }^{1}$ Department of Occupational Medicine, Total E\&P Congo Clinic, Pointe-Noire, Brazzaville, Congo \\ ${ }^{2}$ Faculty of Health Sciences, Marien Ngouabi University, Brazzaville, Congo \\ Email: *ebatetou@gmail.com
}

How to cite this paper: Ebatetou, E.A. Nsemi, J.R.N. and Moukassa, D. (2021) Benzene Monitoring and S-Phenylmercapturic Acid Determination of Workers at Oil Sites in Congo-Brazzaville. Occupational Diseases and Environmental Medicine, 9, 127-138. https://doi.org/10.4236/odem.2021.93010

Received: June 9, 2021

Accepted: July 20, 2021

Published: July 23, 2021

Copyright $\odot 2021$ by author(s) and Scientific Research Publishing Inc. This work is licensed under the Creative Commons Attribution International License (CC BY 4.0).

http://creativecommons.org/licenses/by/4.0/

\begin{abstract}
The toxicity of benzene is well known, and its leukemia effect has established. It is a natural constituent of crude oil and the diseases related to its exposure are recognized as occupational diseases. Objective: To assess occupational exposure of benzene to workers in an oil and gas production company. Materials and Methods: Firstly, it was a descriptive, cross-sectional study which consisted of benzene atmospheric quantification in a sample individual measurement of a homogeneous exposure group of workers. Secondly, urinary assays of S-phenylmercapturic acid have been performed at the end of the shift in the selected workers. Results: The study has included 79 (47.88\%) workers, 17 atmospheric samples were usable and 79 urinary assays at the end of the shift were performed. The average benzene concentration for all sites was 10 times lower than the regulatory average exposure value $\left(1 \mathrm{ppm}=3.2 \mathrm{mg} / \mathrm{m}^{3}\right)$ : average: $0.122 \mathrm{pp}$, median: $0.053 \mathrm{ppm}$ and range: $0.019-1.448 \mathrm{ppm}$. All 79 urinary assays of S-phenylmercapturic acid with a biological exposure index of less than $25 \mu \mathrm{g} / \mathrm{g}$ creatinine: mean: $0.70 \mu \mathrm{g} / \mathrm{g}$ creatinine, median: $0.52 \mu \mathrm{g} / \mathrm{g}$ creatinine and extends: 0.23 to $6.7 \mu \mathrm{g} / \mathrm{g}$ creatinine. Conclusion: Exposure was below to the limit value for benzene in both atmospheric metrology and biometrology. Therefore it is an occupational group with low exposure to benzene. Thus, the medical supervision will be adapted according to the potentially exposing tasks.
\end{abstract}

\section{Keywords}

Benzene, Metrology, S-Phenylmercapturic Acid, Petroleum Site Workers

\section{Introduction}

Benzene or Benzol, which has a very stable aromatic molecular formula, is a 
clear, colorless, volatile, highly flammable liquid. It was isolated by Faraday in 1825 for the first time from a condensed liquid by compression of petroleum gas and first synthesized by Mitscherlich in 1833 [1].

Historically, benzene has been used as a metal degreaser, organic solvent, raw materials and intermediate in the chemical and pharmaceutical industry (e.g.: making rubbers, lubricants, dyes, detergents, and pesticides) and as an additive to unleaded petrol [2]. We can find it in oil products, and it is also added to unleaded gasoline for its anti-knock and octane improvement properties. Nowadays, benzene is mainly used in the petroleum industry and the manufacture of organic chemicals.

Its toxic action on blood lines was suspected as early as 1897 by Lenoir and Claude, and its flattening effect was admitted as a compensable occupational disease in France from January 4, 1931. On the other hand, its proven leukemia effect led to its classification in the group of carcinogens (class 1 carcinogens) for humans by the International Agency for Research about Cancer (IARC) of the World Health Organization (WHO) in 1982 [1].

In industrial toxicology, urinary excretion of S-Phenylmercapturic Acid (SPMA) is well correlated with external exposure of benzene in several studies in occupational subjects and as such, it is one of the metabolites currently considered to be biomarkers of workplace exposure of benzene [3].

In Congo, oil exploration and production began from 1960, but the literature review found no studies conducted among service stations, refinery staff, the oil terminal and workers in the onshore or offshore sites of different oil operators; notwithstanding so exposure of benzene and its analogues is a permanent risk in all petroleum sites in the country because benzene is a natural constituent of crude oil (0.4\%) [4].

In addition, Congolese regulation also recognizes related diseases to chronic exposure of benzene and its derivatives as occupational [5].

Therefore, in view of the findings described before, it appeared necessary to do researches in an oil exploration and production company which objective was to assess occupational exposure of benzene in workers directly exposed.

\section{Materials and Methods of Survey}

\subsection{Setting, Type and Population of Survey}

The study was led by the Department of Occupational Medicine and all onshore and offshore sites of Total Exploration and Production Congo (TEPC), the leading oil company in Congo. This was an observational, descriptive cross-sectional study that took place from 1 October 2017 to 31 December 2017 either a period of 3 months.

The study population was constituted of workers of the present company, who were over 18 years of age and who had freely agreed to take part in the study, working in the external installations of oil sites with a risk of benzene exposure. The sampling technique was systematic and non-probabilistic. It means that the 
rules of selection have allowed to include in the consecutive ways a sample of operators and technicians working in all TEPC's onshore and offshore operational sites.

\subsection{Study Method}

The study was done in two (2) periods.

\subsubsection{First Period: Evaluation of Atmospheric Benzene Using GABIE Badges}

The G.A.B.I.E (Absorbent Gas Badge for Individual Exposure) is a passive sampler designed by the National Institute for Security Research (Institut National de Recherche en Sécurité: INRS) of France. It allows for:

- Passive sampling of gas such as BTX (Benzene, Toluene, Xylene).

- Air sampling in the respiratory area of personnel.

- Determination of the average concentration of these gases during a day working.

- The sample considers the professional gesture and the movements in the work area.

Organic compounds in the atmosphere are captured by diffusion. Then they are trapped on an adsorbent material (active charcoal) at the bottom of the badge (Figure 1 source: https://manualzz.com/doc/5217763/badge-gabie-inforisque.info?).

The badges were given to operators at the beginning of the shift and returned at the end of the shift after a period of 8 hours to 12 hours.

Wearing the badge does not influence the work did by employees neither the preventive or protective measures setting up in the workplace (Figure 2, Ebatetou photo).

At the end of sampling, the badge is closed and stored at room temperature. Then, they were shipped as quickly as possible to an accredited laboratory in France, by plane and analyzing.

Benzene dosage was made by gas chromatography, which is a technical of molecules separation that makes up a gas mixture.
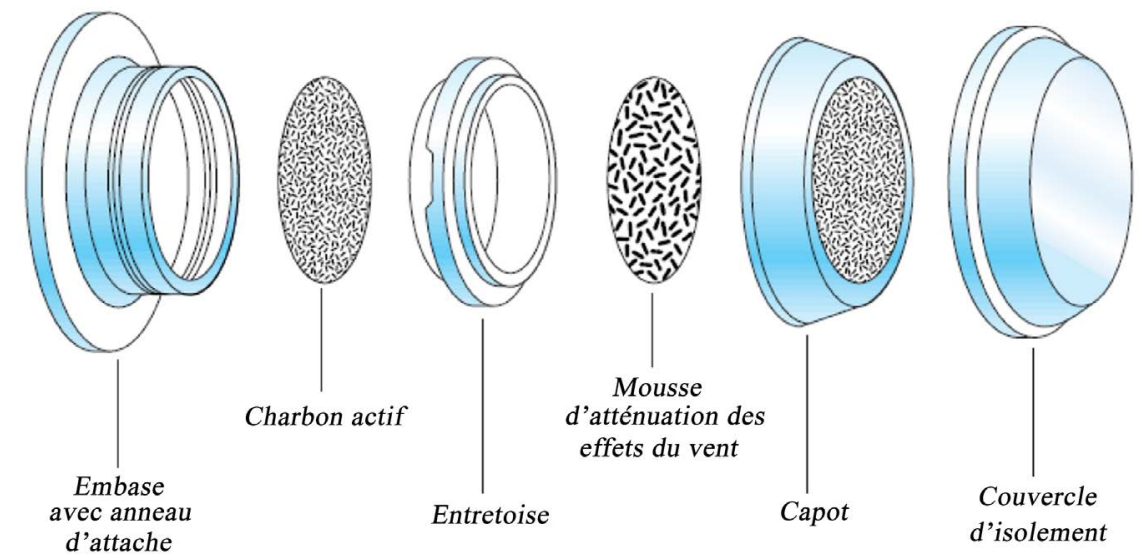

Figure 1. Composition of a GABIE badge. 


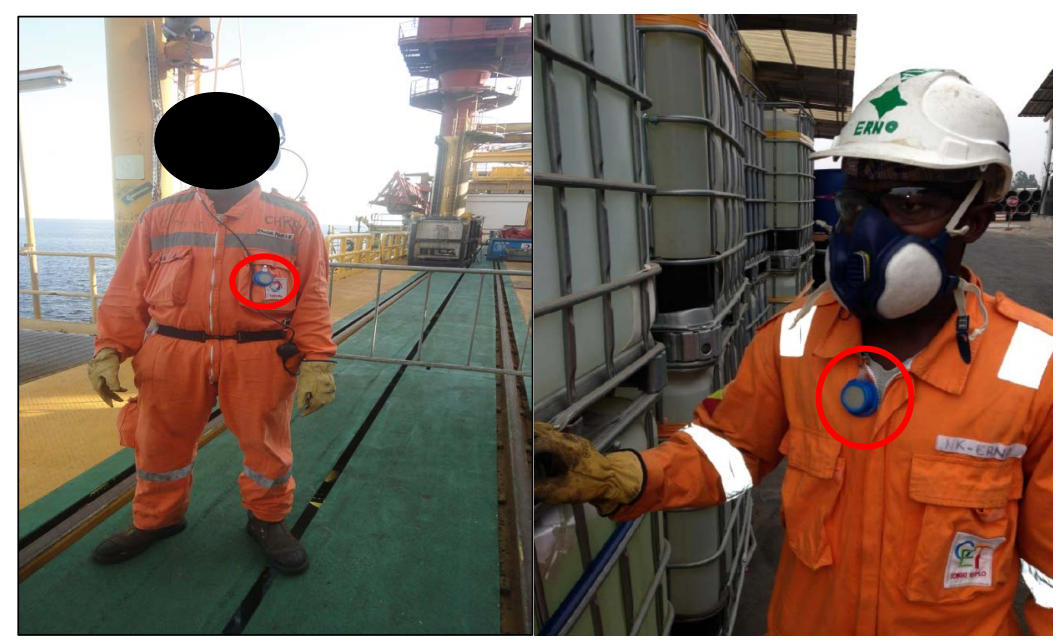

Figure 2. Wearing GABIE badge.

The result is a concentration of vapors collected in ppm (or $\mathrm{mg} / \mathrm{m}^{3}$ ) reported over eight hours. These results show a good average representativity of the daily exposure and are valid for a group of persons belong to the same Homogeneous Exposure Group (HEG).The 8-hour average exposure value (TWA) of benzene, in this oil company is $1 \mathrm{ppm}$ (or $3.25 \mathrm{mg} / \mathrm{m}^{3}$ ).

\subsubsection{Second Period: Urinary Dosage of S-Phenylmercapturic Acid (SPMA)}

Urine was collected from onshore and offshore sites at the end of shift and at the end of rotation.

$2 \times 5 \mathrm{ml}$ of urine was collected from the workers concerned, from 2 specific tubes supplied by the testing laboratory.

After collection, the samples were stored in the freezer $\left(-20^{\circ} \mathrm{C}\right)$ before being transported to France in a carboglace, in the hold, by plane.

The analysis was carried out in the same laboratory as the analysis of GABIE badges.

The biological analyses concerned the liquid chromatography analysis of S-phenylmercapturic acid.

The determination of creatinuria was made by the Jaffe method. Results are rendered by $\mu \mathrm{g} / \mathrm{g}$ creatinine to account for diuresis. The reference value for the professionally exposed population (BEI) is $25 \mu \mathrm{g} / \mathrm{g}$ creatinine.

\subsection{Study Variables}

The various variables of the study were: socio-professional variables (sex, age, job held, place of work, pace of work, seniority, concept of smoking), atmospheric concentration of benzene and urinary S-phenylmercapturic acid.

\subsection{Operational Definitions}

\subsubsection{Operator or Technician}

$\mathrm{He}$ is an oil worker working on an oil rig based at sea or on land. It carries out its 
activity in production or maintenance, contributing to the production of oil. The operator conducts his operations exclusively in the external installations of the oil sites while the technician performs both in the external installations and in the control room which is in the neighborhood.

\subsubsection{Homogeneous Exposure Group (HEG)}

A HEG is a set of persons, positions or work functions for which exposure is of the same nature and intensity.

\subsubsection{Onshore Site}

Onshore means exploration, research, drilling, onshore production, or onshore oil.

\subsubsection{Offshore Site}

The offshore site refers to offshore oil platforms.

\subsection{Statistical Analysis}

The data were entered and processed using Epi-info software version 7.2.2. The various tables and graphs were generated using Microsoft Office Excel 2016. For the quantitative variables, averages, medians, and standard deviations were calculated. The $\mathrm{Khi}^{2}$ and Spearman correlation tests, were used to evidently put association links or to compare the different study variables.

Interpretation of the correlation coefficient $\mathbf{r}$ :

- $\mathbf{r}=0.90$ to 1.00 ( -0.90 to -1.00 ): Very strong positive(negative) correlation

- $\mathbf{r}=0.70$ to 0.90 ( -0.70 to -0.90 ): High positive (negative) correlation

- $\mathbf{r}=0.50$ to 0.70 ( -0.50 to -0.70 ): Moderate positive (negative) correlation

- $\mathbf{r}=0.30$ to 0.50 ( -0.30 to -0.50 ): Low positive (negative) correlation

- $\mathbf{r}=0.00$ to 0.30 ( 0.00 to -0.30$)$ : Negligible correlation

Differences were considered significant when $\mathrm{p}$ was less than or equal to 0.05 $(<5 \%)$; $95 \%$ confidence intervals (5\% margin of error) were calculated.

\section{Results}

\subsection{Socio-Professional Characteristics of the Population}

During the study period, 165 workers were operating on all TEPC operational sites. From the selection criteria that were defined, 79 operators or $47.88 \%$ were selected to constitute the sample of the study. These were mainly workers operating primarily in the external installations of oil sites.

The workers were selected from five (5) sites of the six (6) operational sites available to TEPC. These are the following:

- One (1) onshore site on one (1) (100\%): Djeno oil terminal

- Four (4) out of five (5) offshore sites (80\%): Alima, Nkossa, Yanga and Sendji.

Table 1 shows the breakdown of all workers selected according to their place of work. 
Table 1. Distribution of workers by site.

\begin{tabular}{ccccc}
\hline & & \multicolumn{2}{c}{ Effective } & Percentage \\
\hline & Alima & 11 & 53 & \\
Off-shore & Nkossa & 25 & & \\
& Sendji & 5 & & \\
& Yanga & 12 & & \\
On-shore & Djeno & 26 & & \\
Total & & & 79 & \\
\hline
\end{tabular}

The average age of workers was $33.3 \pm 8.5$ years, the median being 30 years, which is a relatively young population. The extreme ages were 25 and 60 . The 30 - 39 age group was the most represented with 45 workers. All the workers were men.

The shift workers were either $8 \times 8$ days for those working in the onshore site or $14 \times 14$ days for those working in the offshore sites. The daily duration of the shift was 12 hours.

Average seniority was $9.4 \pm 7.9$ years, median 7 years and extremes 4 years and 36 years.

All reported cases of smoking were active, and the average consumption of the overall smoking population was 1 pack/year.

All socio-professional characteristics are shown in Table 2.

\subsection{Benzene Atmospheric Metrology by GABIE Badge}

Of the 24 GABIE badges sent to the laboratory, 17 were usable and 7 had results below detection limits.

The different concentrations of benzene found at the study sites using the GABIE badges are shown in Table 3.

A badge worn on the 17 usable had found a concentration of $1.448 \mathrm{ppm}$, higher than the average exposure value authorized on the company's sites (TWA $=1 \mathrm{ppm}$ ).

The average concentration of benzene at all sites was $0.12 \mathrm{ppm}$, the median $0.053 \mathrm{ppm}$, and the range $0.019-1.448 \mathrm{ppm}$.

\subsection{Determination of S-Phenylmercapturic Acid}

Urine samples from the 79 workers of the study were all usable. The average level of S-phenylmercapturic acid in this study population was $0.70 \mu \mathrm{g} / \mathrm{g}$ creatinine. The median was $0.52 \mu \mathrm{g} / \mathrm{g}$ creatinine with a range of 0.23 to $6.7 \mu \mathrm{g} / \mathrm{g}$ creatinine.

The Spearman $r$ correlation coefficient between worker ages and SPMA assays was 0.22 with a $p=0.54$ and a confidence interval of -0.01 to 0.42 . On the other hand, that between their seniority and the SPMA assays was -0.18 with a $\mathrm{p}=$ 0.11 and a confidence interval of -0.051 to 0.39 . 
Table 2. Distribution of workers by socio-professional characteristics.

\begin{tabular}{|c|c|c|}
\hline Characteristics & Effective & $\%$ \\
\hline \multicolumn{3}{|l|}{ Age (years) } \\
\hline Under 30 years & 27 & 34.2 \\
\hline $30-40$ & 45 & 57 \\
\hline Over 40 years & 7 & 8.9 \\
\hline \multicolumn{3}{|l|}{ Sex } \\
\hline Female & 0 & 0 \\
\hline Male & 79 & 100 \\
\hline \multicolumn{3}{|l|}{ Work rhythm } \\
\hline Daytime & 2 & 2.5 \\
\hline Shift work & 77 & 97.5 \\
\hline \multicolumn{3}{|l|}{ Seniority at the post } \\
\hline Less than 10 years & 57 & 72.1 \\
\hline 10 - 20 years & 15 & 19 \\
\hline More than 20 years & 7 & 8.9 \\
\hline \multicolumn{3}{|l|}{ Smoking } \\
\hline Yes & 3 & 4 \\
\hline No & 76 & 96 \\
\hline \multicolumn{3}{|l|}{ Position type } \\
\hline Operator & 39 & 49.4 \\
\hline Technician & 40 & 50.6 \\
\hline Total & 79 & 100 \\
\hline
\end{tabular}

Table 3. Concentration of atmospheric benzene by site.

\begin{tabular}{|c|c|c|c|}
\hline & GABIE badge number & Benzene concentration (ppm) & Average \\
\hline \multirow{5}{*}{ Djeno } & 1 & 0.053 & \multirow{5}{*}{0.31} \\
\hline & 2 & 0.024 & \\
\hline & 3 & 0.019 & \\
\hline & 4 & 0.02 & \\
\hline & 5 & 1.448 & \\
\hline \multirow{2}{*}{ Alima } & 6 & 0.019 & \multirow{2}{*}{0.036} \\
\hline & 7 & 0.054 & \\
\hline \multirow{4}{*}{ Nkossa } & 8 & 0.021 & \multirow{4}{*}{0.02} \\
\hline & 9 & 0.02 & \\
\hline & 10 & 0.02 & \\
\hline & 11 & 0.019 & \\
\hline \multirow{6}{*}{$\begin{array}{c}\text { Nord } \\
\text { (yanga-sendji) }\end{array}$} & 12 & 0.055 & \multirow{6}{*}{0.061} \\
\hline & 13 & 0.056 & \\
\hline & 14 & 0.053 & \\
\hline & 15 & 0.071 & \\
\hline & 16 & 0.064 & \\
\hline & 17 & 0.066 & \\
\hline
\end{tabular}


No link was found between smoking and SPMA dosing in workers ( $\mathrm{p}=$ 0.5014 ), or between the workstation (technician or operator) and SPMA dosing $(\mathrm{p}=0.5261)$.

\subsection{Atmospheric Benzene Correlation and S-PMA}

The Spearman $r$ correlation coefficient between atmospheric benzene concentrations and S-phenylmercapturic acid assays in workers was 0.09 with a $\mathrm{p}=0.455$ and a confidence interval of -0.15 to 0.31 .

\section{Discussion}

The population of this study was relatively young, with an average age of $33.27 \pm$ 8.5 years and extremes of 25 and 60 years. Technicians and operators represent the lowest level of change in the category of workers at operational sites. These positions are usually filled by those who have recently been hired after a 2-year post-baccalaureate training. This finding is also observed by other authors who find middle ages below 40 years in oil workers: 30.8 years by Hofp et al. in Norwegian offshore [6] and less than 40 years by Gardner in offshore installations of oil industries in Britain [7]. On the other hand, Bratveit et al., in Norway, in a study on benzene biometrology among operators of an oil industry, had recovered an average age of 42.3 years [8].

This youth of the population is perfectly correlated with seniority at the post. In this work, $72.15 \%$ of workers had seniority at the post of less than 10 years with an average of 9.4 years. However, in an American study of the risk of lymphohematopoietic cancers in 25,000 offshore workers exposed to benzene, the average seniority was less than 15 years [9].

The population included in this study was exclusively male. This could be explained, on the one hand, by the difficulty of being a technician or an operator, which requires considerable physical effort, and, on the other hand, by the isolation and exposure to chemicals which counter-indicate work in this environment to breastfeeding and pregnant women. In general, women are naturally excluded from these occupations as soon as they become pregnant for the first time. Hofp et al. [6] and Kirkeleit et al. [10] in Norway in their cohorts of workers at oil sites also had an exclusively male study population. On the other hand, in some studies, in offshore oil sectors, the authors found heterogeneous populations, although mostly male to more than 70\% [8] [11].

The oil sector is one of the sectors, such as the health sector, where activities must be maintained on an ongoing basis. Workers take turns at their shifts for 24 hours a day. In this work, $97 \%$ of the workers included had a shift work rhythm.

The notion of active smoking in this study was found in only $4 \%$ of workers. This concept is sought because tobacco smoke contains benzene [12]. In Hofp's work in Norway, $33.3 \%$ of workers were smokers [6] and 52\% in a study on workers' exposure to benzene in Algeria [13]. The cultural characteristics of each population could be an explanation for the differences observed. 
The exposure of workers to benzene at the various offshore and onshore sites of this company is a reality because benzene is a natural constituent of crude oil and therefore it is a permanent risk. To estimate the actual exposure to benzene in this working environment, reference is made to the measurements taken on working time ( 8 hours or 12 hours) and under normal conditions for the performance of the task. In this work, we used the passive GABIE badges of the INRS for the metrological study of benzene during working time. The GABIE badge is a passive badge that simplifies the measurement of exposures to gases and vapors in industrial atmospheres and allows the level of exposure to benzene and other volatile organic compounds to be defined over 8 working hours. It is therefore comparable to average exposure value [14] [15].

Measurements of average air exposure levels at all sites $(0.12 \mathrm{ppm})$ were below the average exposure value which is set at $1 \mathrm{ppm}$ in this company. On the other hand, the analysis of a GABIE badge assigned to a producer working in an area of high concentration showed higher benzene concentrations equal to $1.448 \mathrm{ppm}$ and therefore higher than the average exposure value. However, there is variability in exposure levels based on the sites, positions and tasks performed by workers.

The benzene vapor exposure data available in the literature relate to operations at offshore sites with values below the average exposure value and like those found in this study. During a regular activity in an offshore oil industry in Norway, the observed extent was $0.001-0.69$ ppm [8]. In Bulgaria, Pesatori et al. found an atmospheric benzene concentration in the range of 0.024 to 0.09 in a study of the early effects of low exposure to benzene among workers in an oil industry [11]. In Norway, Kirkeleit et al., in 2 different benzene exposure studies found average benzene levels of $0.02 \mathrm{ppm}$ [16] and $0.23 \mathrm{ppm}$ [10]; and Hopf et al., which evaluated exposure in offshore petroleum workers, found an average level of atmospheric benzene at $0.02 \mathrm{ppm}$ [6].

S-phenylmercapturic acid is a biomarker of choice for benzene relative to its sensitivity for low ambient exposure to benzene [17] [18] [19]. All urinary assays of this biomarker performed at the end of the shift were lower than BEIs and can be considered as a reflection of very low producer exposure on the day of measurement. This finding, thanks to a biological marker, is consistent with the results of atmospheric sampling. The internal absorbed benzene dose appears to be low. These results are comparable to those described in the literature. These various studies carried out in the oil sector found in their study population very low and lower mercapturic acid concentrations than BEI [6] [10] [16] [17] [19] [20].

In this work, no link was found between SPMA urinary assays on the one hand and on the other hand with the age of the producer, seniority at the post, the workplace, smoking, the concentration of benzene in the ambient air.

The very low level of exposure in the oil sites of this company, the limited sample of the study and the uniqueness of the measurements on a working day, could be an explanation for the lack of correlation between environmental mea- 
surements and biometrology in this work. Moreover, the literature on work carried out at the crude oil production site [17] [20] and at petrol stations [12] [21] finds a good correlation between S-acid levels on the one hand and SPMA and atmospheric benzene concentrations.

The lack of association between smoking and SPMA urinary assays in this work may be due to the very small number of smoking workers in our sample, comparisons under these conditions are not optimal. In contrast, urinary excretion of SPMA acid is known to increase with tobacco consumption [8]. In fact, Boogard et al., in a comparative study of benzene biometrology in the Netherlands, found high levels of SPMA among smokers ( $<$ 0.001) [17].

This study had some limitations. The small sample of this study limits the extrapolation of results to workers at other oil sites in the country. The second limitation was related to the recruitment of a large population of oil workers from subcontracting companies. The latter only worked in the chosen company and not retained because they did not benefit from medical supervision in the occupational health department of the user company. They therefore had no medical records and medical history in the medical department of this company.

\section{Conclusions}

This study quantified benzene exposure among workers at onshore and offshore sites in this oil exploration and production company, while measures to reduce exposure levels are already in place. In normal operation, technicians and operators are very little exposed because the values found in ambient metrology and biometrology are very low compared to occupational exposure limit values and biological exposure indices for all operational sites investigated notwithstanding variability by site and tasks performed.

Ultimately, this is an occupational group with low exposure to benzene.

\section{Recommendation}

Although exposure to benzene is low in this company, we recommend maintaining the preventive measures already in place and adapting and regularity of medical follow-up based on potentially exposing tasks.

\section{Acknowledgements}

Thanks to the participation of the Industrial Hygiene Department of TEPC, the heads of each operational site, as well as the workers, this study was carried out.

\section{Conflicts of Interest}

The authors do not declare any conflict of interest in relation to this article.

\section{References}

[1] Lide, D.R. (2008) CRC Handbook of Chemistry and Physics. Raton, B., Ed., 89th Edition, CRC Press, Florida, 3-32. 
[2] ATSDR (2007) Toxicological Profile for Benzene, $438 \mathrm{p}$. http://www.atsdr.cdc.gov/2007

[3] WHO IPCS-Environmental Health Criteria 150: Benzene. (1993) World Health Organization, International Program on Chemical Safety. http://www.inchem.org/fullist.htm

[4] Wauquier, J.P. (1998) Raffinage du pétrole (Le). Volume 1, Pétrole brut, Produits pétroliers, Schémas de fabrication, Editions Technip, Paris, 2-9.

[5] Congo (1987) Ministry of Labor, Social Security and Justice. Decree No. 87/081 of March 14, 1987. Fixing the Tables of Diseases Considered as Occupational. Official Journal, 7-8.

[6] Hopf, N.B., Kirkeleit, J., Bråtveit, M., Succop, P., Talaska, G. and Moen, B.E. (2012) Evaluation of Exposure Biomarkers in Offshore Workers Exposed to Low Benzene and Toluene Concentrations. International Archives of Occupational and Environmental Health, 85, 261-271. https://doi.org/10.1007/s00420-011-0664-1

[7] Gardner, R.O. (2003) Overview and Characteristics of Some Occupational Exposures and Health Risks on Offshore Oil and Gas Installations. Annals of Occupational Hygiene, 47, 201-210.

[8] Bråtveit, M., Kirkeleit, J., Hollund, B.E. and Moen, B.E. (2007) Biological Monitoring of Benzene Exposure for Process Operators during Ordinary Activity in the Upstream Petroleum Industry. Annals of Occupational Hygiene, 51, 487-494.

[9] Stenehjem, J.S., Kjærheim, K., Bråtveit, M., et al. (2015) Benzene Exposure and Risk of Lymphohaematopoietic Cancers in 25,000 Offshore Oil Industry Workers. British Journal of Cancer, 112, 1603-1612. https://doi.org/10.1038/bjc.2015.108

[10] Kirkeleit, J., Riise, T., Bråtveit, M., Pekari, K., Mikkola, J. and Moen, B.E. (2006) Biological Monitoring of Benzene Exposure during Maintenance Work in Crude Oil Cargo Tanks. Chemico-Biological Interactions, 164, 60-67.

https://doi.org/10.1016/j.cbi.2006.08.017

[11] Pesatori, A.C., Garte, S., Popov, T., Georgieva, T., et al. (2009) Early Effects of Low Benzene Exposure on Blood Cell Counts in Bulgarian Petrochemical Workers. La Medicina del Lavoro, 100, 83-90.

[12] Bensefa-Colas, L., Pineau, F., Hadengue, P., Gennart, J.-P., Choudat, D. and Conso, F. (2009) Occupational Benzene Exposure in Petroleum Products Distribution and Consequences on Medical Surveillance of the Workers. Archives des Maladies Professionnelles et de l'Environnement, 70, 141-151. https://doi.org/10.1016/j.admp.2009.02.012

[13] Djafer, R., Touati, K., Benchaar, M., et al. (2007) Benzene Exposure of Workers in the Coke Plant at the Annaba (Algeria) Steel Complex. Environnement, Risques \& Santé, 6, 37-41.

[14] Delcourt, J. and Sandino, J.P. (2000) Evaluation des performances du badge GABIE ${ }^{\star}$ dans des atmosphères industrielles: Etude de cas. Les Cahiers de notes docu mentaires-Institut national de sécurité, 181, 79-88.

[15] Langlois, E. (2021) Le prélèvement passif des gaz et vapeurs, une méthode simple et performante.

https://www.researchgate.net/profile/Eddy Langlois/publication/306077365 Le preleve ment passif des gaz et vapeurs une methode simple et performante/links/57add85 d08ae95f9d8eccb8a.pdf

[16] Kirkeleit, J., Riise, T., Bråtveit, M. and Moen, B.E. (2006) Benzene Exposure on a Crude Oil Production Vessel. Annals of Occupational Hygiene, 50, 123-129.

[17] Boogaard, P.J. and Van Sittert, N.J. (1995) Biological Monitoring of Exposure to 
Benzene: A Comparison between S-Phenylmercapturic Acid, Trans, Trans-Muconic Acid, and Phenol. Occupational and Environmental Medicine, 52, 611-620.

https://doi.org/10.1136/oem.52.9.611

[18] Boogaard, P.J. and Van Sittert, N.J. (1996) Suitability of S-Phenyl Mercapturic Acid and Trans-Trans-Muconic Acid as Biomarkers for Exposure to Low Concentrations of Benzene. Environmental Health Perspectives, 104, 1151-1157.

https://doi.org/10.1289/ehp.961041151

[19] Ong, C.N., Kok, P.W., Ong, H.Y., Shi, C.Y., Lee, B.L., Phoon, W.H. and Tan, K.T. (1996) Biomarkers of Exposure to Low Concentrations of Benzene: A Field Assessment. Occupational and Environmental Medicine, 53, 328-333.

https://doi.org/10.1136/oem.53.5.328

[20] Ghittori, S., Maestri, L., Fiorentino, M.L. and Imbriani, M. (1995) Evaluation of Occupational Exposure to Benzene by Urinalysis. International Archives of Occupational and Environmental Health, 67, 195-200.

[21] Chakroun, R., Kaabachi, N., Hedhili, A., et al. (2002) Benzene Exposure Monitoring of Tunisian Workers. Journal of Occupational and Environmental Medicine, 44, 1173-1178. https://doi.org/10.1097/00043764-200212000-00012 